\title{
VISUALISING $A$ CRIME IN THE NEIGHBORHOOD THROUGH THE EYES OF A CHILD: DISCOVERY THROUGH EXPERIENCE AND LANGUAGE
}

\author{
Marion Edwards. Universidad de Málaga
}

\begin{abstract}
This is precisely what Suzanne Berne achieves in her novel, A Crime in the Neighborhood, 1999 Orange Prize winner. We are transported back into both the narrator's and our own childhood - reliving experiences, including overhearing 'incomprehensible' adult conversations, musings about unfamiliar words and expressions, impacts of certain vivid memories and events, sibling rivalry, unusual cause-effect relations and the consequences of a lively, creative imagination.

The aim of this article is to analyse Berne's novel, considering both content and language, to examine how Berne succeeds in enabling us to visualise events and experiences in such a convincing, moving and memorable way.
\end{abstract}

\section{INTRODUCTION}

The novel A Crime in the Neighborhood was the winner of the 1999 Orange Prize for Fiction, a prize originally launched in January 1996 by a group of senior women in the publishing industry. Suzanne Berne is a frequent contributor to The New York Times and has published some fiction and essays, although A Crime in the Neighborhood is her first novel, a novel that has been likened several times within reviews to Harper Lee and her To Kill a Mockingbird ${ }^{1}$. Perhaps there is more than just an element of mere chance in these comparisons and recollections. True, we are faced with an adult recounting events occurred in childhood, but we also find another interesting coincidence. Harper Lee's novel is in fact preceded by the following quote from Charles Lamb "Lawyers, I suppose, were

\footnotetext{
${ }^{1}$ Included within the blurb on the Penguin edition, we find the following quotes:

'This ambitious account of a sudden coming of age reminded me strongly of To Kill a Mockingbird and is every bit as moving and as satisfying.' (Daily Telegraph)

'I read a few pages, was captivated, then suddenly found myself on the last page ... Nothing like this has happened to me since I was amazed many years ago by Harper Lee's To Kill a Mockingbird ... Berne trades in the delicacy of suggestion, and her work is all the more affecting because of it. I look forward to reading her again.' (Irish Times)

'The writing is marvellous ... comparisons have been made between her and Anne Tyler and Harper Lee. Same ball-park, delightfully different voice.' (Frances Fyfield. Mail on Sunday)
} 
children once". Berne's novel is actually a first person narration of a thirty-five year old married lawyer, recounting the events that happened in 1972, when she was ten years old, that were to change her life and mark her for ever: a neighbour's boy was murdered and her own father left home. These two events and a series of coincidences trigger off an apparently uncontrollable situation that leads her to do something terrible. As the character-as-narrator concludes in the final chapter:

$\ldots$ in a curious way, I've come to feel grateful to Mr. Green. Because when you have watched yourself do the worst thing you can imagine doing to another person, at least you know what you're capable of. At least you have the rest of your life to be more careful. (247)

We are taken into the past and into childhood where we appreciate complex family relationships, sibling rivalry, guilt about uncomfortable feelings towards people disliked, events that stand out in the narrator's mind, apparently logical connections between occurrences and conclusions. In short, we are offered a piecing together of the past, sometimes with reference to the present, filtered through the eyes, mind and memories of a first person narrator. Lodge (1992:18), dealing with the term "skaz," identifies this apparently-spontaneous first person narration as typical of American writers as a way of "freeing themselves from the inherited literary tradition of England and Europe". In a later publication of 1996, Lodge also affirms that:

First-person narration appeals to contemporary novelists because it permits the writer to remain within the conventions of realism without claiming the kind of authority which belongs to the authorial narrative method of the classic realistic novel. (10)

First-person narration also appeals to us, as readers, as we enter into the intimate world of the narrator - present and past, written in the register of ordinary colloquial speech. We are offered selected events and details that are thought significant in the way that they have affected life both in the past and in particular the present. As is frequent in realist literature, the novel is situated in historical time with multiple references to politicians and real events. Before that summer of 1972, life in the neighbourhood of Spring Hill had been uneventful and normal. However, in 1972, everything changed, with many things occurring both there and in the United States in general, including Governor Wallace being shot in nearby Laurel, the murder of eleven Israeli athletes at the Olympic Games and, of course, the Watergate break-in, which was to leave its mark on American culture ${ }^{2}$. With reference to the "innocence" of the time, the adult-narrator states:

Of course it was still early in 1972. Our neighbors called Nixon Tricky Dick, like everyone else, but joking about crooked politicians was just a way of looking savvy; they didn't believe he was any worse than any other politician. (51)

\footnotetext{
${ }^{2}$ As clearly stated by Snowman and Bradbury (1998: 295): "It was Watergate that became the symbol of the political chicanery and illegality for which the Nixon White House came to stand; Watergate that gave the mid-Seventies its major issue; Watergate that, in 1974, brought about the first presidential abdication in American history; Watergate that was to give the seventies a political colouring of its own."
}

Odisea, $n^{\circ} 2,2002$ 
It is 1972, after all, which if more innocent than our own time is still an era where children know not to talk to strangers. (111)

Little did they know that things were to change so radically. Security is suddenly replaced by violence, normality by the unexpected and innocence by knowledge. The change that has taken place in the narrator is reflected in the following:

Another child might have seized this moment gratefully, broken down, confessed that she was lying - wailed that she was scared, that she'd had a nightmare, any number of plausible, forgivable things - and even then it would have been all right. The whole episode would have been smoothed over somehow and after a few years maybe even forgotten. Unfortunately, I had ceased to be another child some time ago. (213)

Due to the use of direct address, the narratee/implied reader becomes involved with events from the opening pages and the narrator takes us back into the apparent innocence and the inherent excitement of childhood, the intensity of the child's-eye view and the child's visceral delight in exploring and experiencing the world. The narrative involves a dual perspective: the narration of events occurring in the past (memories of the child) and the narration of comments by the adult (opinions related to the childhood experience) ${ }^{3}$. Referring to the murdered boy, the opening lines of Chapter Two take us a step forward into the personal world and the present and past of the narrator:

Why I recall that particular grisly incident so exactly has something to do with my age at the time, and something more to do with what my family was going through that summer, and also with the fact that I knew, very slightly, the boy who had been murdered. But mostly, it has to do with a kind of fanatic vigilance I practiced back then.

If you ask my mother what I was like as a child, she'll tell you that I was one of those little girls who never said much but who was always there, especially during fights. At every spat, every loud argument, every disagreement in the grocery store check-out line, there you'd find me, looking on. (7)

We find a very inquisitive ten-year old Marsha looking on unobserved through partlyajar doors, overhearing telephone conversations, going through the rooms of her older brother and sister and discovering all sorts of things. It is difficult not to become involved in the intimacy and confidentiality implicit here. Even though we learn from the beginning that we will finish the novel without knowing who the child's murderer was, we still read on, fascinated and driven by a deeper curiosity ${ }^{4}$ :

\footnotetext{
${ }^{3}$ This double perspective narrative technique is frequent in memoir novels, cf. Great Expectations, Jane Eyre, Moll Flanders, Catcher in the Rye, etc. Genette (1996:184) employs the terms homodiegetic to define this type of narrator.

4 Within Genette's theory of temporal manipulation, we find analepsis and prolepsis. In general, prolepses or flashforwards are considered fairly unusual in fiction due to the fact that revealing future occurrences removes suspense. However, as Toolan (1988:53-54) points out, "a different kind of engaged puzzlement is fostered by prolepses: the reader is frequently made aware of her own bafflement as to how characters and events get from their current situation to the distant future one prematurely revealed and is all the more intrigued to learn of the intervening happenings". He also points out that proplepsis is more common in first person narrative as being "more natural for such a narrator to jump forward occasionally to subsequent events which are closer to that narrator's own present".
}

Odisea, $\mathrm{n}^{\mathrm{o}} 2,2002$ 
So it's not surprising that although Boyd Ellison's killer has never been found - one of those unfinished stories that sometimes happen in life - as a child I was so anxious to discover him for a while I almost believed I knew who he was. (8)

To be able to understand that story, we need to know another one - Marsha's father had abandoned his wife, daughter and older twin children just before to run away with his sister-in-law - the 'attractive' one that Marsha actually resembles most. One evening at dinner her mother had turned to her father and said, "I know you know I know" and comments the following:

A very strange sentence, I thought at the time. Without understanding what my mother was talking about, I recognized a clutch of implications. What did she know? And how could my father know she 'knew' something and yet have to be reminded about such information? (8)

Marsha takes her father's abandonment personally and cannot understand why he leaves her. Her mother resiliently sets herself to carry on with life and find a way to keep her family, as did her mother before her. The twins, older than Marsha, have one another and with their superior airs and shared complicity, ignore their little sister, using her when expedient, but mostly excluding her. Marsha finds herself spending more and more time alone, writing entries into her Book of Evidence and avoiding Luann, the little friend her mother tries pushing her off with - a precocious eight-year old who provides Marsha with information she is later to attribute to Mr. Green. Driven firstly by the boy's murder, secondly by the fact that the teacher at school is reading The Hound of the Baskervilles and thirdly because she finds herself left to her own devices, Marsha records all the comings and goings in the neighbourhood and produces her Book of Evidence. Annoyed, initially by the fact that she suddenly finds Mr. Green observing her when she is playing and singing by herself in the "shaded corner (...) considered absolutely secret" (53) and, later, by the interest her mother shows in the new neighbour, and, desperate to attract attention to herself, she shows her Book of Evidence to her mother - the facts - and then also adds a few embroidered stories of her own. When her mother refuses to take this seriously and pay much attention, she throws the notebook at her, still expecting and hoping for some kind of reaction. We read:

And perhaps if she had spoken to me then, even told me to go to my room or to wash the dishes, everything might have turned out very differently. But all she said was, 'I've got to get to work.' Stepping over my legs, she left me alone on the porch with my notebook. (185)

However, dismissed once again, she finds someone else to tell her story to and this time, with serious consequences. Reminiscing as an adult ${ }^{5}$, Marsha confides:

\footnotetext{
${ }^{5}$ The echoing words Watch yourself spoken firstly by the detective (108), secondly her mother (168) and then the adult Marsha herself (109) again exemplify temporal manipulation within the narrative. The maturer and wiser Marsha has learned from experience and, in this sense, resembles Pip of Great Expectations or Moll in Moll Flanders. With reference to the latter, Brink (1998:84) refers to "a supposed narrator and a presumed editor"; more significantly, that between an 'experiencing' Moll and a 'narrating' Moll (younger and older versions of herself), which is precisely what we find in Berne's novel - an 'experiencing' Marsha and a 'narrating' Marsha .
} 
Watch yourself: it's advice I have taken to heart. My husband often accuses me of being too fearful, of thinking too much about the calamities that could befall us. I used to defend myself by arguing that I have a good imagination, which allows me to envision calamity in great detail. But the truth is, I watch myself because I can never be sure I won't do something calamitous myself. 'I am careful,' I correct him. (109)

I hope that all the preceding will provide the reader with sufficient insight into the narrative techniques employed and some idea of the intimate tone of the author with a view to providing a context from which to appreciate the way that the childhood experience is portrayed in this novel.

\section{REPRESENTATION OF CHILDHOOD}

While recognising that we have a re-creation of the child's world through the filter of the adult, we can identify certain characteristics in the novel that make us constantly aware of the child's vision of events. Certain aspects are related to the child's perception of sounds, colours, smells and specific scenes that stand out vividly in a cinematic way. Other aspects are related to cognition in general and the child's apparent ignorance about certain concepts, expressions and experiences, although it becomes clear that this ignorance plus a little imagination or intuition provides an awakening of knowledge at this time. Discoveries are made about life, family, sex and self-knowledge. Innocence is lost. With reference to childhood, Philip Thody (1996:60) states the following which reflects extremely well the impressions received when reading this novel:

Childhood is still the period of life in which the emotions are most intense, the hills are greener and the grass is taller. But it is also the period in which our failure as human beings starts to become obvious as well as inevitable.

The aim behind the remainder of this article is to consider how Berne succeeds in depicting childhood experience and the representation of visual and verbal depiction in such an effective and memorable way. Much of the pleasure of reading fiction is not only entering the world of the novel itself, but the way some novels remind us of experiences once lived and forgotten. Many of the observations made by the adult narrator reliving her childhood experiences revive our memories of our own past of not understanding all that is going on - for both linguistic and cognitive reasons. As I mentioned previously, the words "I know you know I know" spark off a surmising about the possible meanings implied. The adult Marsha also adds the comment: "As the youngest of three children, I was used to being unenlightened during dinner-time conversations" (8). Similarly, a reference to "an episode that was to be kept to themselves by adults" is in time solved: "The "episode,' I found out much later, was that Ada and my father had slipped away together for a weekend" (45). Likewise, we have musings and comments on remarks such as the following discovery made in her sister's bedroom:

I also found a poem she had written, slipped between the night table and the baseboard: "Who am I / I am Nobody / I have no Face / I have no Body / I can Only Cry," which I thought was a very good poem, although I couldn't understand how someone with no face could cry. (143) 
Similarly, before he was murdered, the young boy was "molested", presented as follows:

Later that morning, eavesdropping from my bedroom window on Mrs. Bridgeman's conversation with Mrs. Lauder on her front steps, I several times heard a word I didn't understand. Molested. (103)

The narrator's name, Marsha, is frequently taken and played with as so often occurs in childhood. Aunt Ada, her favourite aunt, calls her playfully "Little Miss Marsha, the Martian girl" (15). Her superior twin brother and sister unpleasantly label her "Marsha the Swamp, or simply Swamp" $(19,65,158)$. Her father, who seems very fond of her, calls her 'Marshmallow' (55) and her mother lovingly calls her "Marsha Marsha Martian" (58, 63, 118). Practically everyone has had experiences of their names being played upon sometimes lovingly, others mockingly.

Throughout the novel, there is a certain focalisation on language, reflecting a fascination with language, so typical of the child's discovery of words, sounds and meanings. There are musings on specific words such as the sound of the memorable word "slick" as her mother's definition of her uncle: "her word was 'slick"" (44), her brother's word for breasts "tooties": "He called them "tooties" (22), her father's description of her mother's dress "hotsy totsy": "he had called it her "hotsy totsy dress" (188), her own impressive word "officer of law": "a detective, ('an officer of the law', I began to call him)" (176) and surmising about her mother and aunts using Latin words such as "panis" on the grocery list (12) and "declining Latin verbs (amaveram, amaveras)" (188). Her superior twin brother and sister, Steven and Julie, call themselves Rodney and Felicia and imitate the "aristocratic" English of Evelyn Waugh's characters as in "Rodney, you gourmet fiend" (64) and "We'll have to start snitching ciggies from the madre. Think, Rodney. Menthol. Quelle horror" (158). Nixon's expression 'My fellow Amaricans' (50) is mused upon, as is her mother's use of 'pièce de résistance' in the following "She called the table her 'pièce de résistance" (37). The persona also comments on the irony behind the name of the extremely tall detective who visits them: "His name was Detective Robert Small, which I remember thinking was funny because he was so tall that he had to stoop as he came through the door" (108).

All this reminds us of the delight in discovery of language by children, a delight in playing with language, which is at the same time characteristic of postmodernist and contemporary writers. Berne borrows from and incorporates various genres and sub genres, written in varying idiolects, such as journal and diary entries (217), newspaper headlines and articles $(112-113,205)$, a personal letter (72), a work schedule (68), a shop assistant name plate (Hi I'm BYRON: Have a nice day) (146), a flyer (123), an anonymous letter (123), the already-cited poem (143), the "script" her mother uses when selling magazines over the phone (68), a piece from the CBS News (Evening News with Walter Cronkite) and includes an article supposedly from the Washington Post (120). All this intertextuality is woven into the narrative in an effective and convincing way as part of the child's discovery of life, experience and especially language.

Another example of the child's interpretation of the world in words apparently understood but misinterpreted due to lack of cognitive development, commented on by the adult Marsha, is the following: 
Mrs. Morris told me the cups were all that remained of her mother's bone china. In one of those surreal misapprehensions that make childhood so interesting, I thought the cups were made from her mother's bones. (74)

However, the most outstanding features of the narrative of this novel are the cinematic effects reflecting the vivid scenes, sounds and movements of memories of images and events recalled and scenarios depicted in the narrator's mind. ${ }^{6}$ This highly sensorial imagery is achieved through the deliberate selection and careful organisation of lexical items. Although written in apparently spontaneous colloquial language, closer examination reveals specific characteristics, including the use of dynamic, semantically-loaded verbs with phonaesthesic ${ }^{7}$ effects, minute detail achieved through concrete nouns and adjectives chosen for associative meanings, frequent use of simile, all carefully combined to contribute to the sensual qualities related to vision, sound and also smell in some cases.

The following paragraph may serve as an example which includes visual effect, movement and sound:

My mother picked up her plate, and with a snap of her wrist, sailed it like a Frisbee straight across the dining room. China shattered. Mashed potatoes and gravy splattered against the wall and onto the blue carpet and sprayed my father's white shirt with grease spots. One half-eaten pork chop landed on top of the china cabinet. (8-9)

Likewise, in the following paragraphs, we have similar examples of alliteration, verbs of movement plus lexis chosen for associative meaning and connotation:

Downstairs, the washing machine chugged into a new phase of its cycle; water swished and the pipes rattled. Outside, a car rushed past our house, honking its horn. (...) Across the street, the Morrises' dogs began barking, adding to the chorus of banging pipes and the chuntering washer and the humming refrigerator and the slow ticking of the sunburst wall clock. (173)

And then suddenly there was Mr Green looming bulkily from behind a lilac bush. (53) June arrived. School ended. Hurricane Agnes slammed into town, tore off tree branches and knocked down power lines and left lake-sized puddles in the street. (54)

\footnotetext{
${ }^{6}$ This cinematic effect is obviously deliberate: numerous direct references to the media appear in the novel and in similes including the following: "None of these people bears much resemblance to the people I knew. Like cartoons, a few features remain recognisable in magnified form" (29-30). "A moment later, Mr. Morris's stooped silhouette passed his drawn living-room blind, like something from a Hitchcock movie" (92).

${ }^{7}$ Phonaestheme is the term originally used by Firth (1964:184) and 'phonaesthesia' is defined as the study of the expressiveness of sounds. Other terms found within Stylistics are phonaestasia, sound symbolism, secondary onomatopoeia, protosemanticism, psychomorphs/submorphemic differentials (Bolinger, 1965) Cratylism (Genette, 1980), etc. Although linguistic studies frequently refute theories related to 'sound symbolism', insisting on the arbitrariness of language, I would emphasise that I coincide with Firth's interpretation of phonaesthesia regarding speech sounds as meaning-bearing as a result of 'phonetic habit' due to 'an attunement of the nervous system' rather than due to inherent meaning of sound. Certain lexical items are felt by native speakers to be appropriate to their signifieds with reference in particular to sounds, movements and other sensorial properties, e.g., association of fast movement with verbs beginning in fl-, as in flee, flip, flap, flicker, flash, flutter, flitter, flick, fling, etc. unpleasantness with words commencing sl- slip, slide, slither, slink, sly, sleazy, slimy, slippery, slop, etc.
}

Odisea, $\mathrm{n}^{\circ} 2,2002$ 
Another particularly vivid and dynamic paragraph is this last one selected for the different types of movement included:

I tried to stop myself from repeating stinker, stinker, shivering while Mrs. Morris's head wobbled, while her dogs lunged away from her ankles, their toenails skittering on our cement front steps, while a crow flapped into the crab-apple tree, while my mother stood at the door, shaking her head in time to Mrs. Morris's shaking.

A close study of the above-mentioned lexical items within the novel reveals the extensive use of phonaesthesic lexis related to the following groups. As to be expected, there are abundant examples relating to sounds. We find repeated use of the following, many of which are monosyllabic and include recurring consonant clusters: clink, clank, clatter, chug, chunter, patter, rattle, rustle, rumble, drone, drip, snap, bang, twang, whack, whirr, whine, wail, whimper, wheeze, squeak, creak, crack, crackle, crash, tick, tap, knock, bump, grunt, scrub, scour, throb, buzz, honk, hiss, swish, gabble, etc. Regarding different manners of speaking, we find mutter, murmur, moan, groan, scream, shriek, rasp, wail, whimper, howl, yowl, bicker, gabble.

With reference to verbs of movement with manner included, we find abundant use of the following, all of which are visually effective and rich in connotations: crawl, creep, crouch, snake, slither, slant, drag, stump, stalk, skulk, trail, lope, lurch, loom, trudge, slide, squat, stoop, prop, shift, spurt, trickle, dangle, shrink, hobble, hunch, clump, jiggle, joggle, jerk, stagger, sway, skittle, toss, trot, rush, rock, dart, duck, shift, flap, buck, bumble, bunch, huddle, sail, sling, drift, whiz, zig-zag, hover, spring, flutter, shake, whicker, tremble, shudder, twitch, flinch, wave, quake, quaver, swirl, stir, eddy, waver, flicker, wobble, bob, nod, wag, spit.

These verbs of movement including manner information, the majority of which are monosyllabic and originally from Old English, Old Danish and Old Norse, are commonly found in the register of colloquial speech in English. They frequently appear combined with prepositions indicating direction and often cause difficulties for interpretation by speakers of languages such as Spanish and other Romance languages where the movement or direction appears in the main verb, and manner, if included, is provided by an adverbial ${ }^{8}$. These basic structural differences also result in specific problems in translation between English and Spanish'.

Within verbs related to ways of looking, seeing and facial expressions, we find varying lexical items with various connotations and associations: gaze, glance, glare, stare, scan, skim, gawk, peer, squint, blink, wink, twitch, wrinkle, frown.

Verbs of perception relating to light include: flicker, flash, flush, shimmer, gleam, glint; and relating to water: spatter, spurt, spray, sprinkle.

Verbs of touching / hitting include: tap, slap, slam, swat, smash, flip, dab, pat, pound, elbow, knee, pinch, all of which are manner-specific. We also find several examples of ways of holding / taking: clutch, clasp, grope, grip, riffle, pluck, grab, snatch, wrench, yank, clamp, brandish, fumble, finger.

\footnotetext{
${ }^{8}$ Within research in Cognitive Linguistics, languages have been found to be classifiable into two groups. Spanish and other Romance languages, Semitic languages and Japanese are verb-framed, whereas English and other Indo-European languages (Romance excepted), Finno-Ugric languages and Chinese are satelliteframed (Talmy, 1991, cited in Slobin, 1999:195).

${ }^{9}$ See Edwards, 2001.
}

Odisea, $n^{\circ}$ 2, 2002 
The use of all these lexical items entailing detailed sound, manner and movement associations makes the prose exceptionally vivid for the reader, contributes to the cinematic effect and detail and intricacy of the child's eye view. This is, in my view, how Berne succeeds in invoking "the period of life in which the emotions are more intense, the hills are greener and the grass is taller" (Thody, 1996:60).

With reference to the second part of the above quotation, "But it is also the period in which our failure as human beings starts to become obvious as well as inevitable", we can say that Berne convincingly conveys the child's fascinated but morbid interest in death, cruelty, sex, adult behaviour, etc. when she finds such pleasure in her voyeurism as reflected in the following:

I edged around so that I could squint through the crack between the hinges and the doorjamb, hoping, and fearing, but hoping most intensely that my aunts would take off their clothes. (21-22)

Likewise, we appreciate the ambivalence of her fascinated reaction to the dissected praying mantis, which is one of both horror and attraction:

Stomach heaving, I drew closer and stared, wanting to get even closer, to peer right into those alien eyes. What I felt, as I stared at that mutilated insect wasn't pity; it was closer to a lost word between revulsion and desire. I wanted to put the praying mantis into my mouth. (116)

We can appreciate clear feelings of guilt towards her own behaviour here as in also her fascination with mould, slugs, ants, her guilt in deliberately provoking her mother's anger to the limits and her voyeurism. This guilt and the incomprehensibility about why she finds defiance and wrongdoing so attractive and satisfying reflects to a certain extent her insecurity in general about life and particularly with reference to her own identity. Is she the face without a mouth of the poem? Which Marsha is she? Why does her father abandon her? Why does her mother not pay more attention to her? Why does all that happens happen? "Why" is significantly also the only word that Mr. Green ever says to her afterwards. It is as though "why" was the key word behind the novel: why did her father leave? Why was the boy murdered? Why did she do what she did? Why did everything change? As the persona also states:

I always wanted a reason. 'Why?' I asked my mother, my father, anyone who would listen. 'Why did it happen?' I was fascinated by how people managed to hurt one another, by what could make them want to do it. (7)

Not only is there horror regarding her own inexplicable feelings, but there is also realisation about the hypocritical behaviour of adults, including gossiping, cliquishness, misrepresentation of the truth: "Naturally, my mother never said any of the things she reported herself as saying" (13). The loss of the child's innocence at this time is reflected in the neighbourhood:

But you have to understand that twenty-five years ago a murder in a suburban area like Spring Hill was still an astonishing occurrence, so astonishing that for a long time the people who lived there felt somehow responsible, as if they should have 
foreseen something so unforeseen. Like my mother, they felt guilty for having ever felt secure. (102)

These words are also echoed in the following review that appeared in the Chicago Tribune: ${ }^{10}$

This backward glance at childhood transcends the genre with its distinctive style and atypical narrator. Its local crimes of betrayal and violence are the believable jolts of daily life, the kind that leave everybody involved 'guilty for having felt secure.'

The feeling of loss is emphasised in the final paragraph of the novel when we read how she feels when she learns that her father is dead:

Suddenly there I was, ten years old all over again, and he had just left me, and the world was a wide place in the dark, and right then I understood as if for the very first time that nothing in my life would ever feel safe. (248)

\section{CONCLUSIONS}

In my opinion, Berne has produced a multifaceted novel that combines memories of childhood experience involving cognitive development in general and language in particular, reflected in childhood comments and losing of innocence, fine psychological observation related to the worlds of both child and adult, intricate personal relationships and aspects of modern life. It is through her choice of narrative technique and selection of lexis that she succeeds in achieving immediacy in the narration of thoughts and events: first person narration and other techniques including direct address, effective use of shifts in time and lively exchanges and dialogues, invite the reader into the intimate world created in the novel. The language of the novel is carefully selected and intricately organised to activate images, sounds and associations in the reader's mind. This is done through the use of deliberate collocation of similar sounding words with phonaesthesic associations. Language in both narration and dialogue is varied and dynamic, and the linguistic elements mentioned previously also provoke vivid images in the reader's mind. This is how I believe Berne succeeds in writing a novel which is so convincing, moving and memorable.

\section{REFERENCES}

Berne, S. 1998 (1997). A Crime in the Neighborhood. Harmondsworth/New York: Penguin.

Brink, A. 1998. The Novel: Language and Narrative from Cervantes to Calvino. London: Macmillan.

Bolinger, D. L. 1965. Forms of English: Accent, Morpheme, Order. Cambridge, MA: Harvard University Press.

Edwards, M. 2001. "Making the implicit explicit for successful communication: pragmatic differences between English and Spanish observable in the translation of verbs of movement". Revista Alicantina de Estudios Ingleses, 14: 21-35.

\footnotetext{
${ }^{10}$ Vid note 1.
} 
Firth, J.R. 1964 (1930). 'The Tongues of Men' and 'Speech' . London: Oxford University Press.

Genette, G. 1996 (1972). "Voice”. Narratology: An Introduction. Eds. S. Onega and J.A. García Landa. London/ New York: Longman. 172-89. . 1980. "Valéry and the poetics of language". Textual Strategies: Perspectives in Post-Structuralist Criticism. Ed. J. V. Harari. London: Methuen.

Lee, H. N. 1983 (1960). To Kill a Mockingbird. London: Heinemann.

Lodge, D. 1992. The Art of Fiction. Harmondsworth: Penguin. . 1996. The Practice of Writing. London: Secker and Warburg.

Slobin, D. I. 1999 (1996). "Two ways to travel: verbs of motion in English and Spanish" Grammatical Constructions: Their Form and Meaning. Eds. M. Shibatani and S.A.Thompson. Oxford: Oxford University Press. 235-287.

Snowman, D. and M. Bradbury. 1998. "The sixties and seventies" Introduction to American Studies. (Third Edition). Eds. M. Bradbury and H. Temperley. New York: Longman. 272-303.

Thody, P. 1996. Twentieth-Century Literature: Critical Issues and Themes. London: Macmillan.

Toolan, M.J. 1988. Narrative: A Critical Linguistic Introduction. London/New York: Routledge. 